Joslin, E. P., Root, H. F., White, P., Marble, A., and Bailey, C. C. (1946), Treatment of Diabetes Mellitus, 8th ed.

Lawrence, R. D. (1955). The Diabetic Life, 15th ed., p. 161. Churchill, London.

L!amas, R., and Molina, A. V. (1955). Rev. Invest. clin., 7, 143.

Marble, A. (1946). New Engl. J. Med., 211, 339.

Pygott, F., and Osborn, H. (1937). Lancet, 1, 1461.

Ross, C. F. (1951). Brit. J. Surg., 39, 53.

Schlesinger, F. G., Schwarz, F., and Wagenvoort, C. A. (1960). Acta med. scand., 166, 337.

Silver, G. B., and Lubliner, R. K. (1948). Surg. Gynec. Obstet., 86, 703.

Sproul, E. E. (1938). Amer. J. Cancer, 34, 566.

Urmy, T. V. O., Jones, C. M., and Wood, J. C. (1931). Amer. J. med. Sci., 182, 662 .

Wilder, R. M. (1940). Clinical Diabetes Mellitus and Hyperinsulinism, p. 306. Saunders, London.

Willis, R. A. (1952). The Spread of Tumours in the Human Body, 2nd ed. Butterworth, London.

\section{INHERITANCE OF HAEMOCHROMATOSIS}

\section{A REPORT ON A FAMILY WITH CONSANGUINITY}

BY

\section{R. H. DAVISON, M.A., M.B., M.R.C.P.Ed. Lately Medical Registrar, Worthing Hospital}

Idiopathic haemochromatosis results from an inborn error of metabolism in which excessive absorption of iron from the gut leads to massive deposition of iron throughout the body. Although the disease usually occurs sporadically, a familial incidence is now well recognized, and has been reported on a number of occasions (Sheldon, 1935 ; Lawrence, 1935, 1949 ; Nussbaumer et al., 1953; Houston and Zilkha, 1955; Houston, 1957 ; McAlpine, 1959). The consanguinity of the parents has received attention in only one of these papers (Nussbaumer et al.). The familial incidence is of considerable importance, as it must be taken into account in any theories on the aetiology of this disease.

This paper reports a family in which a brother and sister have the disease and another sister, otherwise well, has a raised serum iron. Consanguinity is present, the patients' mother having married an uncle. The family pedigree is :

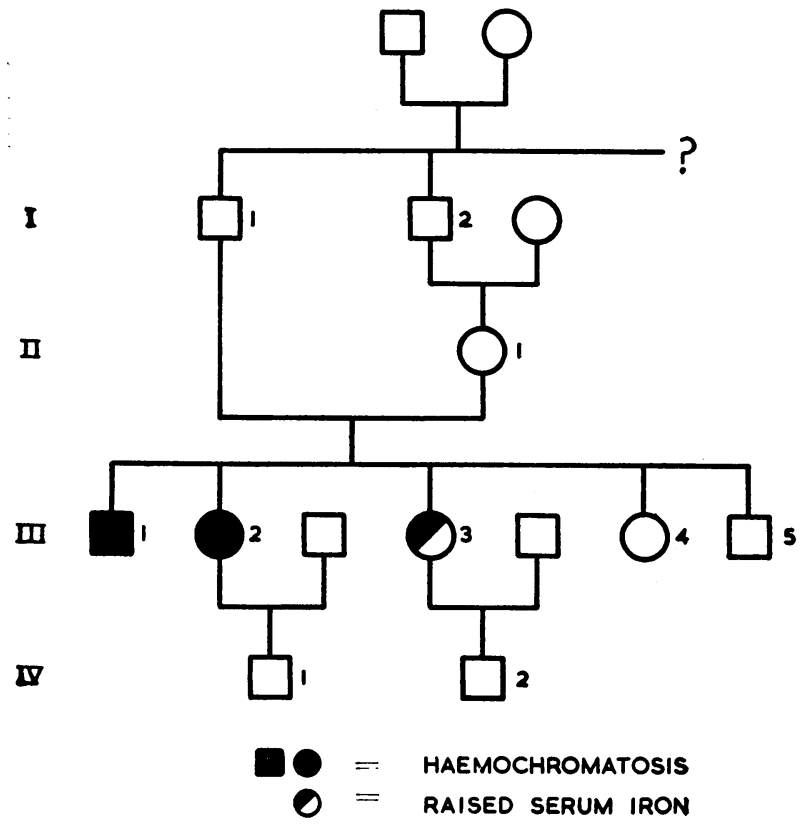

\section{Case Report}

A housewife aged 55 was seen in August, 1960, complaining of fatigue and intermittent diarrhoea for four months. Her husband said that she had become increasingly forgetful and lethargic over the previous 12 months, often forgetting her shopping and other household duties. Menstruation started when she was 13 and was scanty, seldom lasting more than two days (her sister gave a similar menstrual history). The menopause was at 48 . Her past medical history was not helpful. She had lived a good deal of her life abroad as her husband was in the consular service, and during a two-year stay in the Far East had been taking oral iron for an unspecified illness.

Family History.-The pedigree shows a brother (III 1) who died in France in 1948 when he was 43 and who had been treated in a Parisian hospital for diabetes and hepatic cirrhosis during the war. His sisters said he had always been a "funny colour." Another brother (III 5) was a deaf mute and at the time of writing was still alive in France, but nothing further was known. A sister (III 4) died of an infection aged 7, and another sister (III 3) has been examined and found to have slight pigmentation of the forearms and a serum iron of $232 \mu \mathrm{g} . / 100 \mathrm{ml}$. The ironbinding capacity was fully saturated. Both the patient (III 2) and this sister are married, and each has a son. Neither of these boys has evidence of haemochromatosis. The patient's son (IV 1) had a serum iron of $60 \mu \mathrm{g} . / 100 \mathrm{ml}$. and her nephew (IV 2) had a serum iron of $158 \mu \mathrm{g} . / 100 \mathrm{ml}$. The iron-binding capacity was $330 \mu \mathrm{g} . / 100 \mathrm{ml}$., and the glucose-tolerance test normal. The patient's parents are both dead. The mother (II 1) died aged 80 of carcinomatosis after a carcinoma of the breast. No other abnormalities were noted during life; necropsy was not performed. The father (I 1) died aged 75 from coronary thrombosis and carcinoma of the bladder. Necropsy showed chronic venous congestion of the liver and histological changes of an early mild portal cirrhosis. He was not a diabetic.

Examination.-There was a slaty-grey pigmentation. especially on the face, neck, and forearms. Axillary and pubic hair was scanty, and numerous spider naevi were present over the arms and chest. The liver and spleen were both palpable two fingerbreadths below the costal margin, and felt very hard. No clinical abnormality was present in the other systems. The urine contained a trace of albumin and $2 \%$ sugar.

Investigations.-Blood count: $\mathrm{Hb} 85 \%$; W.B.C. $4,2 \mathrm{Cn}$ (normal differential); E.S.R. $36 \mathrm{~mm}$. (Wintrobe). Blood sugar $240 \mathrm{mg} . / 100 \mathrm{ml}$. Serum iron $330 \mu \mathrm{g} . / 100 \mathrm{ml}$. I.B.C. fully saturated. Liver-function tests: total proteins $6.7 \mathrm{~g} .1$ $100 \mathrm{ml}$. (albumin $4.5 \mathrm{~g}$., globulin $2.2 \mathrm{~g}$.), electrophoretic strip showed some increase in $\alpha_{2}$-globulin. Flocculation tes:s normal. S.G.O.T. 75 units $/ \mathrm{ml}$. S.G.P.T. 58 units $/ \mathrm{ml}$. E.C.G.: sinus rhythm; rate $66 / \mathrm{min}$.; P-R 0.2 second: inverted $T$ waves in leads II, III, aVF, and V1-6; R-T segments depressed in II and III, and raised in V4-6. Liver biopsy: there was a well-established fibrosis of the interportal connective tissue and fibrous distortion of the lobes ; both connective tissue and hepatic cells contained excessive deposits of coarse haemosiderin; haemofuscin not evident. Skin biopsy: pigmentation of basement membrane of sweat glands, but diagnostically inconclusive. Marrow puncture: normal cytology; granules of free iron pigment were scattered sparsely between the cells, and a few intracellular aggregations were present; the total amount was small. C.S.F.: normal manometrics and cells, etc. ; glutamine level $22.7 \mathrm{mg}$. $/ 100 \mathrm{ml}$. Urine 17 -ketosteroids $0.8 \mathrm{mg}$./day. Kepler coefficient 8.8 . Urine 17 -ketosteroids $8.3 \mathrm{mg}$./day after 20 units of A.C.T.H. for seven days. Fishbach and Rous tests both negative. $X$-ray examination of chest and skull showed nothing abnormal. Straight $x$-ray film of abdomen showed some splenic calcification, but the hepatic shadow was normal. 


\section{Discussion}

There is a high incidence of raised serum-iron levels, diabetes, cirrhosis, and occasionally pigmentation in the siblings of haemochromatotic patients. Bothwell et al. (1959) report 107 siblings, of whom half were affected. Finch and Finch (1955) found that $20 \%$ of relatives had raised serum-iron level, and Debré et al. (1952) have reported a similar incidence. The exact mode of inheritance in this disorder has been difficult to discern, however.

According to Neel and Schull's (1954) thesis, idiopathic haemochromatosis is a familial disorder due to an autosomal gene which is transmitted as a Mendelian dominant, though with incomplete penetrance. Bothwell et al. believe that there is not only incomplete penetrance but also variable expressivity. The family reported here is interesting not only because of the consanguinity of the parents, but because neither parent showed any of the usual stigmata of the disease during life. There seems, therefore, no reason why the inheritance should not be through an autosomal recessive gene. Debré et al. (1958) in Paris believe that the increased rate of iron absorption characteristic of haemochromatosis may be determined by a single gene. When inheritance is homozygous an uncommon and fulminating type of haemochromatosis may result. In the heterozygous state a milder form is seen, with later onset of symptoms and signs. This is certainly in keeping with the clinical features of the family reported here. Some inquiry into the family pedigree and investigation of the relatives is clearly most important in this disease, and may often reveal both clinical and subclinical cases.

\section{Summary}

A family is described in which two siblings have haemochromatosis and another has a raised serum iron. The parents were related, the patient's mother having married an uncle.

The disorder is probably transmitted by an autosomal recessive gene.

The importance of examining a patient's relatives in tracing subclinical cases is emphasized.

I thank Dr. H. I. C. Balfour and Dr. J. F. P. Skrimshire for permission to publish this case and for their help and encouragement. I am grateful to Dr. C. O. Carter, of the Medical Research Council Genetics Unit. Great Ormond Street Hospital for Sick Children, for reading the manuscript and making several helpful suggestions.

\section{REFERENCES}

Bothwell, T. H., Cohen, I. Abrahams, O. L., and Perold, S. M. (1959). Amer. J. Med. 27, 730

Debré, R., Dreyfus, J., Frézal, J., Labie, D., Lamy, M., Maroteaux, P.. Schapira, F., and Schapira, G. (1958). Ann. Hum. Genet.., 23. 16.

Schapira, G., Dreyfus, J., and Schapira, F. (1952). Bull. Soc. méd. Hồp. Paris, 68, 665

Finch, S. C., and Finch, C. A. (1955). Medicine (Baltimore), 34, 381 .

Houston, J. C. (1957). Brit. med. Bull., 13, 129.

— and Zilkha. K. J. (1955). Guy's Hosp. Rep., 104, 262

Lawrence, R. D. (1935). Lancet, 2, 1055.

(1949). Ibid., 1, 736.

McAlpine, S. G. (1959). Brit. med. J., 2. 618.

Neel, J. V., and Schull, W. J. (1954). Human Heredity. Univ. Chicago Press.

Nussbaumer, T.. Plattner, H. C., and Rywlin, A. J. (1953). Génét. hum., 1. 53.

Sheldon. J. H. (1935). Haemochromatosis. Oxford Univ. Press, London.

\section{CONTROLLED TRIAL OF "VIRUGON" IN TREATMENT OF MEASLES}

BY

\author{
E. J. HOPKINS, M.B., Ch.B.
}

ANNE M. PYE, M.B., B.Ch., L.M.

M. Solomon, M.B., Ch.B., D.P.H.

AND

SYLVIA SOLOMON, M.B., Ch.B.

General Practitioners, Liverpool

We were interested in the claim that $N^{1}, N^{1}$-anhydrobis ( $\beta$-hydroxyethyl) biguanide hydrochloride (A.B.O.B.) is an effective and non-toxic antiviral agent. It is marketed in this country in combination with the solanaceous alkaloids atropine methonitrate and scopolamine methonitrate, which are thought to have a synergistic effect, under the trade name of "virugon." Several workers believe that it is of value in the prevention (Bateson, 1960 ; Bohmansson, 1960 ; Haglind, 1960 ; Sandahl and Sjöberg, 1960 ; Sjöberg, 1960a) and treatment (Stenkula, 1959 ; Sjöberg, 1960a, 1960b) of influenza.

There is evidence that A.B.O.B. administration reduces the mortality in young hamsters injected intra. cerebrally with measles virus (Farquhar, 1960). Moreover, during an outbreak of measles 21 (24\%) out of 88 patients on placebo tablets developed the disease but only $11(12 \%)$ out of 90 patients on A.B.O.B. were affected. However, A.B.O.B. did not seem to affect the severity of the measles in the cases in which it occurred. But it could be argued that A.B.O.B. prevented the occurrence of the very mild cases of measles and reduced the severity of the potentially severe cases to average level.

Farquhar (1960) also quotes a "double-blind" trial of A.B.O.B. in the treatment of children with measles in which no significant difference was noted between the two groups. However, there were only five treated children and five controls in this investigation, and the tablets were not given until approximately one day after the rash appeared.

We decided to carry out a double-blind trial to see if virugon really was effective in the treatment of measles.

\section{Method}

During a period of six months, beginning in December, 1960, 41 patients with measles seen in our urban practice in North Liverpool were each given a bottle of tablets. The tablets contained either $100 \mathrm{mg}$. of virugon or a placebo. Each bottle was labelled with a code number, so that reference to a key, after the record card had been completed, enabled us to find whether

\begin{tabular}{|c|c|c|}
\hline & Virugon Series & Controls \\
\hline $\begin{array}{l}\text { Total No. } \\
\begin{array}{l}\text { Sex ratio, males/females } \\
\text { Average age }\end{array}\end{array}$ & $\begin{array}{c}19 \\
13 / 6 \\
4.6 \text { years }(\mathrm{S} . \mathrm{D} .=2) \\
\text { (Standard error of }\end{array}$ & \begin{tabular}{|c|}
22 \\
1111 \\
4.1 years $($ S.D. $=2)$ \\
difference $=0.63)$
\end{tabular} \\
\hline $\begin{array}{l}\text { No. with Koplik's spots ... } \\
\text { Time patients first seen and treat } \\
\text { ment begun: } \\
2 \text { days before rash appeared } \\
\text { Day ", } \\
\text {," of onset of rash } \\
\text {," after onset of rash }\end{array}$ & $\begin{array}{r}11 \text { out of } 19(58 \%) \\
1 \\
2 \\
13 \\
3\end{array}$ & $\begin{array}{r}11 \text { out of } 21(52 \%) \\
0 \\
2 \\
14 \\
6\end{array}$ \\
\hline
\end{tabular}

D 